\title{
Dampak Konvergensi IFRS, Karakteristik Perusahaan, dan Kualitas Auditor Terhadap Audit Delay
}

\author{
DWI RATMONO* \& PUSPA AVINDA DWI SEPTIANA \\ Program Studi Akuntansi, Universitas Diponegoro, Jl. H. Prof. Soedarto, SH. - Tembalang Semarang, 50275, Telp. +62 2476486851 / 76486853 , \\ Indonesia \\ *Corresponding Author, E_mail address: dwi_ratmono@yahoo.com
}

\begin{abstract}
The objective of this study is to examine the influence of IFRS implementation on the audit delay. To focus on the impact of audit delay, this study controls the effect of company's characteristics. Characteristics of the company used in this study are the company size, the leverage, and the loss announcement. The population used in this study is all of the manufacturing company listed in Indonesia Stock Exchange for 2010 until 2013 period. The study uses the purposive sampling for the sampling method. The criteria of the sample which is used is company must have published audited financial report for four years successively and used Rupiah, so that the number of the sample in this study is 416 observations. There are two variables that do not affect the audit delay, those IFRS implementation, and loss announcement. The results shows that the company size, leverage and the auditor's quality significantly affect audit delay.

Keywords: audit delay;IFRS Implementation;Company's Characteristics; Auditor's Quality.
\end{abstract}

\begin{abstract}
ABSTRAK
Tujuan dari penelitian ini adalah menguji pengaruh implementasi IFRS terhadap audit delay. Dalam rangka memfokuskan pada dampak audit delay, penelitian ini mengendalikan pengaruh karakteristik perusahaan seperti ukuran perusahaan, leverage, dan pengumuman rugi. Populasi penelitian ini adalah semua perusahaan manufaktur yang terdaftar di Bursa Efek Indonesia untuk periode 2010-2013. Penelitian ini menggunakan teknik penyampelan dengan tujuan (purposive sampling) sebagai metode sampling. Kriteria yang digunakan adalah perusahaan harus mempunyai laporan keuangan auditan yang dipublikasikan selama 4 tahun secara konsisten dan menggunakan mata uang Rupiah sehingga diperoleh 416 observasi. Terdapat dua variabel yang tidak mempengaruhi audit delay yaitu implementasi IFRS dan pengumuman rugi. Hasil pengujian menunjukkan bahwa ukuran perusahaan, leverage, dan kualitas auditor berpengaruh signifikan terhadap audit delay.

Kata Kunci:Audit Delay;Implementasi IFRS; Karakteristik Perusahaan; Kualitas Auditor
\end{abstract}

\section{PENDAHULUAN}

Ketepatwaktuan dalam pelaporan keua-ngan (timeliness of financial reporting) merupakan salah satu kriteria kualitas informasi akuntansi. Informasi dalam laporan keuangan agar dapat digunakan untuk membuat keputusan yang relevan maka laporan keuangan harus disajikan tepat waktu dan akurat. Nilai dari ketepatwaktuan pelaporan keuangan merupakan faktor penting bagi kemanfaatan informasi dalam laporan keuangan terkait dengan relevansi informasi. Hal ini karena semakin lama waktu laporan keuangan diterbitkan ke publik, tingkat akurasi dan relevansi infor-masi yang ada akan semakin menurun. Hal tersebut nantinya menyebabkan keputusan yang dihasilkan dari laporan tersebut menjadi kurang andal.

Dalam rangka mencapai ketepatwaktuan dalam penyajian laporan keuangan auditor independen pada masa sekarang ini menghadapi beberapa masalah yang dapat menyebabkan lamanya proses penyelesaian audit (audit delay). Beberapa faktor yang dapat memperpanjang audit delay seperti kompleksitas perusahaan, ukuran perusahaan, jenis 
industri, dan sistem pengendalian internal perusahaan (Yacoob dan Ayoib, 2012). Dengan adanya hambatan - hambatan inilah yang memungkinkan auditor untuk menunda publikasi laporan audit dan memperpanjang masa audit atau yang biasa disebut audit delay.

Konvergensi International Financial Reporting Standards (IFRS) di beberapa negara juga menjadi faktor yang menyebabkan semakin lamanya waktu audit. Hal ini karena penerapan IFRS merupakan hal yang baru sehingga perlu dipelajari dan dipahami terlebih dahulu termasuk oleh auditor (Yacoob dan Ayoib, 2012). Pene-rapan IFRS juga membutuhkan pengung-kapan yang lebih luas dan menggunakan lebih banyak fair value yang menyebabkan auditor membutuhkan waktu dan usaha yang lebih dalam melakukan audit. Auditor juga dituntut mengumpulkan bukti yang lebih banyak untuk meyakinkan kebenaran penyajian laporan perusahaan. Dengan kondisi-kondisi tersebut memung-kinkan auditor untuk menunda publikasi laporan audit dan laporan keuangan auditan apabila dirasakan perlu untuk memperpanjang masa audit.

Karakteristik perusahaan yang berbeda-beda juga dapat mempengaruhi waktu penyelesaian audit. Dengan karakteristik perusahaan yang berbedabeda ini auditor akan membutuhkan sejumlah pengumpulan bukti yang berbeda-beda sesuai dengan kondisi perusahaan, hal ini akan berpengaruh pada panjang pendeknya waktu audit. Karakteristik perusahaan yang digunakan antara lain ukuran perusahaan, pengumuman rugi dan tingkat leverage perusahaan. Selain karakteristik perusahaan, kualitas auditor juga memiliki kualifikasi yang berbeda-beda. Kualitas ini nantinya dapat mempengaruhi waktu penyelesaian audit. Hal tersebut kaitannya dengan kualitas sumberdaya manusia dan infrastruktur auditor yang berbedabeda.
Penelitian ini bermaksud menganalisis hubungan antara penerapan pengadopsian IFRS di Indonesia terhadap audit delay. Hal ini penting diteliti karena dampak konvergensi IFRS pada audit delay masih terbatas bukti empirisnya (Yacoob dan Ayoib, 2012). Penelitian ini berkontribusi pada literatur akuntansi dengan memberikan bukti empiris dampak fenomena penerapan IFRS pada audit delay. Hasil penelitian ini diharapkan dapat menjelaskan ketidak-konsistenan hasil penelitian terdahulu tentang dampak penerapan IFRS pada IFRS pada audit delay. Untuk menjelaskan ketidak-konsistenan tersebut, penelitian ini menambahkan faktor-faktor seperti kualitas auditor, ukuran perusahaan, leverage, dan pengumuman rugi untuk diuji pengaruhnya terhadap audit delay. Dengan memasukkan variablevariabel tersebut ke dalam model penelitian diharapkan dapat diperoleh validitas internal hasil penelitian yang lebih memadai.

Penelitian ini juga berkontribusi pada praktik dan kebijakan terkait impelementasi IFRS. Hasil penelitian ini dapat menjadi bahan evaluasi bagi regulator seperti Dewan Standar Akuntansi Keuangan (DSAK) Ikatan Akuntan Indonesia terkait kompleksitas standar akuntansi berbasis IFRS yang mereka susun. Demikian juga bagi Badan Pengawas Pasar Modal dan Lembaga Keuangan dalam menyikapi kemungkinan keterlambatan penyampaian laporan keuangan karena implementasi IFRS. Penelitian ini juga diharapkan berkontribusi dengan mem-berikan bahan evaluasi bagi Kantor Akuntan Pubik (KAP) dalam menyiapkan para auditornya untuk dapat menyesuaikan dengan IFRS sehingga tidak menurunkan kinerjanya dalam melakukan audit.

\section{TINJAUAN LITERATUR DAN PERUMUSAN HIPOTESIS AUDIT DELAY}

Audit delay merupakan topik menarik bagi para 
stakeholder, auditor juga perusa-haan. Hal ini karena audit delay dapat mempengaruhi kualitas keputusan yang akan dibuat oleh para stakeholder. Kualitas keputusan tersebut terkait dengan relevansi informasi keuangan perusahaan. Karena semakin lama audit delay semakin berkurang tingkat relevansi laporan keuangan tersebut. Hal ini akan mempengaruhi keakuratan pembuatan keputusan stakeholder yang secara langsung maupun tidak langsung akan mempengaruhi keputusan investasi pada perusahaan. Banyak faktor yang dapat menyebabkan penyajian laporan keuangan tidak tepat waktu, atau dengan kata lain mengalami audit delay. Salah satu faktor yang dapat menyebabkan audit delay adalah penerapan IFRS.

IFRS masih pada tahap awal penera-pannya di Indonesia. Tahapan awal penera-pan IFRS dapat menyebabkan auditor memerlukan waktu dan tenaga lebih banyak untuk memverifikasi penerapan IFRS perusahaan sudah sesuai dengan standar yang berlaku. Penggunaan fair value yang lebih banyak dibandingkan peraturan sebelumnya juga mendukung semakin kompleksnya pemeriksaan yang dilakukan oleh auditor. Ini sejalan dengan penelitian yang dilakukan Yaacob dan Ayoib (2011) yang menemukan bahwa penerapan IFRS di Malaysia mempengaruhi secara positif audit delay. Artinya dengan adanya penerapan IFRS di Malaysia maka berpengaruh terhadap lebih panjangnya waktu yang dibutuhkan auditor untuk menyelesaikan audit. Yacoob dan Ayoib juga melakukan penelitian tentang IFRS pada tahun 2012 dengan proksi FRS 138. Hasilnya Yacoob dan Ayoib (2012) menemukan bahwa penerapan FRS 138 mempengaruhi secara positif audit delay. Artinya, dengan adanya penerapan FRS 138 tingkat audit delay di Malaysia semakin meningkat.

Berdasarkan uraian di atas, dapat dirumuskan hipotesis sebagai berikut:

$H_{1}$ : Penerapan IFRS memiliki pengaruh positif pada audit delay

Variabel independen kedua adalah ukuran perusahaan. Terdapat berbagai cara untuk mengukur perusahaan. Salah satunya dengan menggunakan total aset yang dimiliki perusahaan. Ukuran perusahaan juga dapat berpengaruh terhadap audit delay. Perusa-haan yang besar memiliki kemampuan untuk mendorong auditor untuk menyelesaikan audit tepat waktu. Beberapa penelitian sebelumnya mendukung pernyataan ini. Sebagai contoh, hasil penelitian Owusu-ansah (2000), Kartika (2009), Ahmad (2003) dan Margaretta (2011), menyatakan bahwa audit delay memiliki hubungan negatif dengan ukuran perusahaan. Artinya bahwa semakin besar aset perusahaan maka semakin pendek audit delay.

Dari penelitian terdahulu dapat disim-pulkan bahwa ukuran perusahaan akan berpengaruh secara negatif terhadap audit delay (Owusu-ansah, 2000),. Hal tersebut karena semakin besar perusahaan maka perusahaan memiliki kemampuan untuk mendesak auditor untuk melakukan audit lebih cepat. Selain itu, perusahaan yang ukurannya besar cenderung diberikan tekanan lebih besar untuk melakukan audit dengan cepat karena ada monitor yang ketat dari pihak eksternal yang menggunakan laporan keuangan seperti pemegang saham. Hal ini karena pemegang saham berkepentingan terhadap hasil investasi mereka. Berdasarkan uraian di atas, dapat dirumuskan hipotesis sebagai berikut:

$\mathrm{H}_{2}$ : Ukuran perusahaan memiliki penga-ruh negatif terhadap audit delay

Variabel leverage terkait dengan kemampuan perusahaan membayar hutang. Tingkat leverage besar sering diidentikan dengan kinerja perusahaan yang buruk. Hal ini menyebabkan auditor akan melakukan audit lebih lama. Hal ini sejalan dengan penelitian yang dilakukan oleh Febrianty (2011). 
Dalam penelitiannya yang menggunakan sampel perusahaan sektor perdagangan yang listing di BEI pada tahun 2007-2009 menemukan bahwa terdapat pengaruh positif antara audit delay dengan tingkat leverage perusahaan. Hal tersebut karena leverage mengindikasikan buruknya keuangan perusahaan, yang akan membuat auditor meningkatkan perhatiannya pada laporan keuangan perusahaan. Selain itu alasan lainnya yang diungkapkan oleh Febrianty (2011) meng-audit utang membutuhkan waktu yang lebih lama ketimbang mengaudit modal. Beberapa hasil penelitian mendukung adanya pengaruh positif leverage terhadap audit delay (Owusu-ansah (2000), Ahmed (2003), Febrianty, 2011). Berdasarkan uraian di atas, dapat dirumuskan hipotesis sebagai berikut:

$H_{3:}$ Leverage memiliki pengaruh positif terhadap audit delay

Variabel pengumuman rugi terkait dengan badnews yang disampaikan perusahaan. OwusuAnsah (2000) dan Wiwik Utami (2006) mengungkapkan perusahaan yang memiliki kinerja baik (good news) akan melaporkan lebih tepat waktu dibandingkan dengan perusahaan yang mengalami kerugian (bad news). Perusahaan yang menderita rugi cenderung meminta auditor untuk menunda publikasi laporan keuangannya agar tidak mempengaruhi keputusan investor. Penjelasan ini sejalan dengan teori sinyal yang menyebutkan bahwa perusahaan dengan kondisi yang baik akan dengan sengaja memberi sinyal pada pasar. Hal ini juga sejalan dengan penelitian Iskandar dan Trisnawati (2010) yang mengungkapkan audit delay dapat dipengaruhi oleh kerugian yang dialami perusahaan. Jika perusahaan mengalami rugi maka auditor cenderung berhati-hati dalam memastikan nilai kerugian sehingga proses audit akan lebih panjang (Iskandar dan Trisnawati, 2010). Berdasarkan uraian diatas, dapat dirumuskan hipotesis sebagai berikut:

$\mathrm{H}_{4}$ : Pengumuman rugi memiliki pengaruh positif terhadap audit delay

Untuk pengukuran kualitas auditor digunakan jenis Kantor Akuntan Publik (KAP). KAP yang berafiliasi dengan big four memiliki kualitas auditor yang lebih baik dibanding dengan non big four. Kualitas auditor ini juga ditentukan oleh sumberdaya yang dipekerjakan di KAP tersebut. Iskandar dan Trisnawati (2010) beranggapan bahwa KAP yang lebih besar dinilai lebih mampu melaksanakan audit secara efisien dan lebih efektif daripada KAP yang lebih kecil serta memiliki fleksibilitas dalam menjadwal pelaksanaan audit sehingga audit dapat diselesaikan secara tepat waktu. Selain itu, KAP besar diyakini dapat memberikan keyakinan yang lebih mengenai kualitas auditor. Penelitian ini juga sejalan dengan penelitian yang dilakukan oleh Wiwik Utami (2006) serta Iskandar dan Trisnawati (2010). Mereka menemukan bahwa Perusahaan yang diaudit oleh KAP yang berafiliasi dengan KAP asing mengalami audit report lag yang lebih pendek. Dari penjelasan diatas terbentuk hipotesis bahwa KAP yang berafiliasi dengan big four memiliki kualitas yang lebih baik dan hal ini akan memperpendek audit delay. Hal ini juga karena KAP tersebut mempertahankan reputasi mereka. Maka hipotesis yang dibuat sebagai berikut:

$\mathrm{H}_{5}$ : Kualitas auditor memiliki pengaruh negatif terhadap audit delay

\section{METODE PENELITIAN}

\section{MODEL PENELITIAN}

Berdasarkan perumusan hipotesis, maka dibuat mdel penelitian sebagaimana yang disajikan pada Gambar 1. 


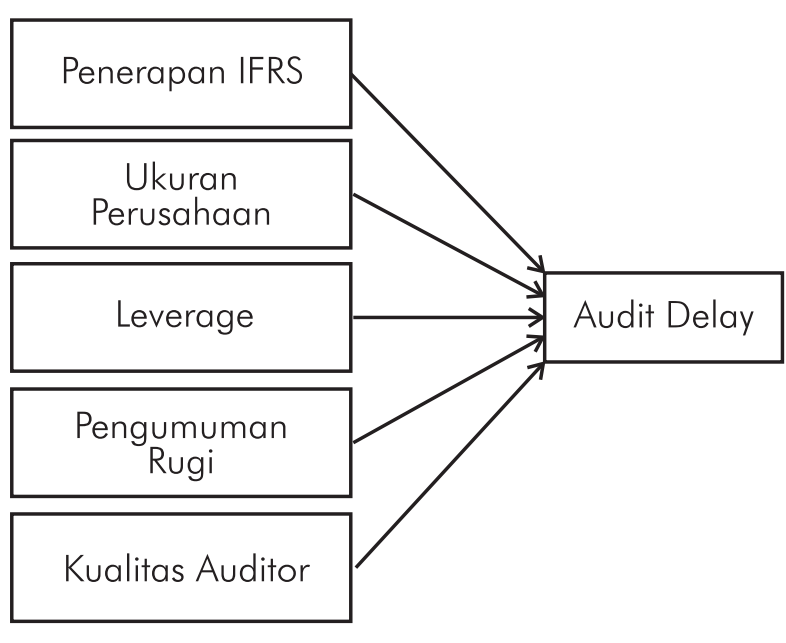

GAMBAR 1. MODEL PENELITIAN

\section{VARIABEL PENELITIAN}

Berdasar penelitian Yacoob dan Ayoib (2012), maka variabel penerapan IFRS diukur dengan menggunakan variabel dummy. Pada periode penerapan IFRS maka perusahaan akan diberikan nilai 1 , jika tidak maka perusahaan akan diberi nilai O. IAI mencanangkan bahwa standar akuntansi internasional (IFRS) berlaku di Indonesia pada tahun 2012 secara keseluruhan (www.iaiglobal.or.id). Oleh sebab itu maka: Nilai 1 diberikan untuk periode observasi pada tahun 2012 dan 2013. Nilai 0 diberikan untuk periode observasi tahun 2010 dan 2011. Cara mengukur ukuran perusahaan adalah menghitung total aset yang dimiliki perusahaan. Untuk menghitung leverage caranya dengan membagi total utang dibagi dengan total aset. Variabel pengumuman rugi diukur dengan menggunakan variabel dummy. Perusahaan akan diberi nilai satu jika mengalami rugi dan akan diberi nilai nol jika sebaliknya. Cara mengukur variabel kualitas auditor adalah dengan menggunakan variabel dummy. Nilai satu diberikan jika perusahaan diaudit oleh KAP big four. Sedangkan jika selain big four maka akan diberi nilai nol.

\section{PENENTUAN SAMPEL}

Pemilihan sampel menggunakan metode purposive sampling. Dalam penentuannya ditetapkan kriteria: pertama, perusahaan manufaktur berturutturut terdaftar di Bursa Efek Indonesia pada tahun 2010, 2011, 2012, dan 2013. Kedua, laporan perusahaan lengkap selama 4 tahun

\section{METODE ANALISIS}

Metode analisis yang digunakan untuk menguji hipotesis dalam penelitian ini adalah regresi linier berganda. Regresi ini digunakan untuk menguji pengaruh beberapa variabel independen (independen) terhadap satu variabel dependen. Berikut ini merupakan persamaan regresi linier berganda yang digunakan dalam penelitian ini:

$$
D E L A Y=\propto+\beta_{1} I F R S+\beta_{2} A S E T+\beta_{3} L E V E R A G E+\beta_{4} R U G I+\beta_{5} K A P+\mu
$$

DELAY: Waktu antara tanggal tahun berakhir laporan tahunan perusahaan dengan tanggal laporan auditan

IFRS: Periode penerapan IFRS

ASET: total asset yang dimiliki perusahaan LEVERAGE: Total liabilitas/total aset

RUGl: Laba/rugi tahun berakhir

KAP: Auditor eksternal perusahaan

\section{HASIL DAN PEMBAHASAN}

Berdasarkan sampel yang telah diamati maka ditetapkan 416 data yang digunakan dalam penelitian ini. Sampel tersebut terdiri dari 104 perusahaan setiap tahunnya.

\section{TABEL 1. STATISTIK DESKRIPTIF}

\begin{tabular}{lllll}
\multicolumn{5}{c}{ Panel A: Variabel Non-Katagorikal } \\
\hline & Minimum & Maksimum & Rata-rata & Deviasi Std. \\
\hline DELAY & 31 & 150 & 76,59 & 15,44 \\
ASET & $10,5 \mathrm{M}$ & $213.994 \mathrm{M}$ & $6.376 \mathrm{M}$ & $19.168 \mathrm{M}$ \\
LEVERAGE & 0,03 & 3,34 & 0,54 & 0,48
\end{tabular}


Panel B: Variabel Katagorikal

\begin{tabular}{lllll}
\hline Variabel & Pengukuran & Jumlah & $\%$ & DELAY \\
\hline \multirow{2}{*}{ RUGI } & 1 Rugi & 68 & $16 \%$ & 82 hari \\
& O Laba & 348 & $84 \%$ & 75 hari \\
\multirow{2}{*}{ KAP } & 1 Big Four & 184 & $44 \%$ & 73 hari \\
& 0 Non Big Four & 232 & $66 \%$ & 78 hari \\
\hline
\end{tabular}

Pada tabel di atas terlihat bahwa variabel DELAY yang menggambarkan panjang waktu pelaporan keuangan memiliki nilai maksimum sebesar 150 hari yang dimiliki oleh perusahaan Sunson Textile Manufacture pada tahun 2011 Sedangkan waktu delay paling pendek (nilai minimum) adalah sebesar 31 hari yang dimiliki oleh perusahaan Holcim Indonesia Tbk pada tahun 2010. Rata-rata panjang delay 416 perusahaan ini adalah 76 hari. Waktu audit delay ini lebih pendek dibandingkan waktu audit delay pada penelitian sebelumnya yaitu penelitian Yacoob dan Ayoib (2012). Pada penelitian sebelumnya di Malaysia ratarata waktu penyelesaian waktu audit adalah 100 hari. Variabel audit delay memiliki standar deviasi

15,32. Standar deviasi audit delay lebih kecil dibandingkan dengan nilai rata-ratanya, dengan kata lain simpangan data yang ada relatif kecil, artinya nilai dari setiap sampel berada disekitar ratarata hitungannya.

Variabel aset memiliki rata-rata $\mathrm{Rp}$ 6.376.518.273.672 dengan nilai maksimum $\mathrm{Rp}$ 213.994.000.000.000 yang dimiliki oleh perusahaan Astra Internasional pada tahun 2013. Nilai terendah dalam sampel tersebut adalah sebesar Rp 10.582.842.395 yang dimiliki oleh PT Alam Karya Unggul Tbk. Artinya PT Alam Karya memiliki ukuran paling kecil diantara keseluruhan sampel.

Variabel leverage sendiri memiliki rata-rata 0,54 dengan standar deviasi 0,48 . Tingkat leverage paling tinggi dimiliki oleh perusahaan Asia Pasific Fibers sebesar 3,34. Tingkat leverage terendah dalam sampel adalah sebesar 0,03 yang dimiliki oleh perusahaan Jaya Pari Steel, artinya kemampuan aset perusahaan tersebut untuk menutupi utang/ liabilitas hanya 3\%.

Variabel IFRS, RUGI, dan KAP merupakan variabel dummy yang memiliki nilai 1 dan nilai 0 . Pada Variabel penerapan IFRS nilai 1 diberikan ketika periode penerapan IFRS, sedangkan nilai 0 diberikan untuk periode sebelum penerapan IFRS. Oleh sebab itu, pada tahun 2012 dan 2013 seluruh perusahaan diberi nilai 1 . Nilai 0 diberi untuk perusahaan pada tahun 2010 dan 2011 karena IFRS belum diterapkan secara penuh pada periode tersebut. Pada periode penerapan IFRS perusahaanperusahaan yang menjadi sampel mengalami delay selama 76 hari sedangkan sebelum periode penerapan mereka mengalami delay selama 76 hari dari statistik deskriptif ini tidak ditemukan perbedaan antara periode setelah penerapan IFRS dan periode sebelum penerapan IFRS

Variabel RUGI juga merupakan variabel dummy. Perusahaan akan diberi nilai 1 jika mengalami kerugian, sedangkan perusahaan yang mengalami laba akan diberi nilai 0. Dari jumlah sampel 416 perusahaan sampel yang ada $16 \%$ sampel mengalami kerugian. Terdapat perbedaan waktu audit delay pada perusahaan yang mengalami kerugian dan perusahaan yang mendapat keuntungan. Pada perusahaan yang mengalami kerugian memiliki rata-rata audit delay sebanyak 82 hari. Sebaliknya, perusahaan yang mendapat keuntungan memiliki waktu audit delay yang lebih pendek yaitu sebanyak 75 hari.

Variabel terakhir yang menggunakan dummy adalah kualitas auditor yang diwakili oleh KAP. Variabel ini akan diberi nilai 1 jika perusahaan diaudit oleh KAP yang berafiliasi dengan big four, sedangkan 0 jika diaudit oleh non big four. Dari 416 sampel sebanyak 184 perusahaan diaudit oleh KAP big four sedangkan 232 perusahaan diaudit oleh non big four. KAP big four rata-rata mengalami delay 
selama 73 hari sedangkan KAP non big four mengalami delay rata-rata selama 78 hari.

Sebelum dilakukan analisis hasil pengujian hipotesis, terlbeih dahulu dilakukan evaluasi hasil pengujian asumsi regresi ordinary least squares (OLS) atau asumsi klasik. Hasil pengujian menunjukkan tidak ada masalah multikolinearitas yang ditunjukkan dengan nilai variance inflation factor (VIF) di bawah nilai 10 .

TABEL 2. RINGKASAN HASIL UJI HIPOTESIS

\begin{tabular}{llll}
\hline VARIABEL & KOEFISIEN & NILAI P & HASIL \\
\hline IFRS & $-0,19$ & 0,88 & $\mathrm{H}_{1}$ ditolak \\
ASET & $-6,60$ & 0,02 & $\mathrm{H}_{2}$ diterima \\
LEVERAGE & 3,92 & 0,07 & $\mathrm{H}_{3}$ diterima \\
RUGI & 4,67 & 0,11 & $\mathrm{H}_{4}$ ditolak \\
KAP & $-4,24$ & 0,052 & $\mathrm{H}_{5}$ diterima \\
\hline Adjusted R- square & 0,05 & & \\
Prob (F stat) & 0,000014 & & \\
\hline
\end{tabular}

Demikian juga hasil pengujian Glejser dan Durbin-Watson (DW) menunjukkan tidak ada masalah heteroskedastisitas dan autokorelasi. Hasil pengujian Kolmogorov-Smirnov menunjukkan bahwa asumsi normalitas juga telah terpenuhi. Dengan demikian data penelitian dapat digunakan untuk tahap pengujian hipotesis (Ghozali, 2011).

Output sebagaimana yang disajikan pada Tabel 2 merupakan hasil dari pengolahan regresi linier berganda. Untuk bagian ini akan dibahas hasil uji koefisien determinasi. Penelitian ini menggunakan nilai adjusted $R$ Squared untuk mengevaluasi model regresi. Hasil regresi menunjukan bahwa nilai Adjusted $R$-squared sebesar 0,05 artinya 5\% variasi DELAY yang digambarkan oleh variabel IFRS, ASET, LEVERAGE, RUGI, dan KAP, sedangkan sisanya dijelaskan oleh sebab lain diluar model.

Uji selanjutnya yang akan dibahas adalah uji statistik F. Uji statistik F menunjukkan apakah semua variabel independen yang dimasukkan dalam model mempunyai pengaruh secara bersama- sama terhadap variabel dependen, dan untuk menguji apakah model regresi yang digunakan sudah tepat. Apabila nilai probabilitas lebih kecil daripada 0,05, maka model regresi tersebut dapat digunakan untuk memprediksi pengaruh variabel independen terhadap variabel dependen. Dari hasil output diketahui bahwa probabilitas uji $\mathrm{F}$ adalah 0,000014 nilai ini berada dibawah 0,05 artinya model regresi tersebut dapat digunakan untuk memprediksi pengaruh variabel independen terhadap variabel dependen.

Dari lima variabel independen yang dimasukan kedalam model regresi terdapat dua variabel yang tidak signifikan. Salah satu variabel yang bernilai tidak signifikan adalah variabel penerapan IFRS. Variabel penerapan IFRS memiliki nilai signifikansi sebesar 0,88. Nilai koefisien variabel sebesar 0,19 dengan nilai yang negatif. Dari data nilai signifikansi variabel dan koefisien yang ada tersebut, maka $\mathrm{H}_{1}$ dalam penelitian ini ditolak. Artinya, tidak terdapat pengaruh antara penerapan IFRS dengan audit delay. Penjelasan dari hasil ini mungkin terjadi karena IAI sebagai lembaga yang bertang-gungjawab dalam merumuskan standar telah berhasil mensosialisasikan mengenai perubahan standar yang terjadi sehingga baik manajemen maupun auditor sudah siap saat terjadinya penerapan standar baru yang berbasis IFRS.

Auditor yang melakukan audit juga sudah memiliki kemampuan yang memadai sehingga penerapan peraturan baru tidak begitu mempengaruhi kinerja auditor dalam melakukan audit. Hasil tersebut sejalan dengan Margaretta (2011) dalam penelitian-nya yang berjudul Pengaruh Penerapan IFRS Terhadap Keterlambatan Waktu Penyam-paian Laporan Keuangan Pada Perusahaan Manufaktur Yang Terdaftar di Bursa Efek Indonesia. Hasil penelitian Margaretta (2011) tersebut menyebutkan bahwa penerapan IFRS tidak 
memiliki pengaruh signifikan terhadap audit delay. Namun, hasil ini bertolak belakang dengan penelitian yang dilakukan oleh Yaacob dan Ayoib (2011). Yaacob dan Ayoib menemukan bahwa adopsi IFRS mempengaruhi secara positif audit delay.

Dalam model regresi terlihat bahwa variabel ASET yang mewakili variabel ukuran perusahaan memiliki nilai signifi-kansi sebesar 0,02 dan memiliki koefisien yang bernilai negatif. Karena nilai signifi-kansinya berada dibawah 5\% dan memiliki koefisien yang bernilai negatif, maka $\mathrm{H}_{2}$ dalam penelitian ini diterima. Artinya, Ukuran perusahaan memiliki pengaruh pada audit delay dengan arah yang berlawanan, jika perusahaan besar maka audit delay cenderung pendek begitu pula sebaliknya. Hasil sesuai dengan penelitian yang dilakukan oleh Kartika (2009), Owusu-Ansah (2000), serta Ahmed (2003) Penelitian mereka membuktikan bahwa ukuran perusahaan berhubungan negatif dengan audit delay. Margaretta (2011) juga mendapat hasil yang sama dalam penelitian-nya meskipun menggunakan proksi yang berbeda yaitu log pendapatan. Hal tersebut karena semakin besar perusahaan maka perusahaan memiliki kemampuan untuk mendesak auditor untuk melakukan audit lebih cepat.

Selain itu, perusahaan yang ukurannya besar biasanya lebih banyak mendapat tekanan dari stakeholder yang memiliki andil dalam perusahaan untuk menerbitkan laporan tepat waktu sehingga mereka dapat menggunakan informasi tersebut dalam membuat keputusan. Perusahaan juga mendapat pengawasan yang banyak dari pihak eksternal sehingga perusahaan akan berusaha menerbitkan laporan keuangan lebih awal. Namun, hasil tersebut bertolak belakang dengan hasil yang didapat oleh Yaacob dan Ayoib (2012), serta Haryani dan Wiratmaja (2014). Mereka menemukan bahwa tidak terdapat pengaruh antara audit delay dengan ukuran perusahaan.

Variabel leverage merupakan salah satu variabel yang bernilai signifikan. Variabel ini memiliki nilai signifikansi sebesar 0,07 dengan nilai koefisien yang bernilai positif. Dari hasil regresi variabel ini maka bisa diambil kesimpulan bahwa terdapat hubungan positif antara leverage perusahaan dengan audit delay, yang artinya $\mathrm{H}_{3}$ dalam penelitian diterima. Hasil penelitian ini sejalan dengan hasil penelitian yang dilakukan oleh Febrianty (2011). Dalam penelitiannya Febrianty (2011) dapat membuktikan bahwa leverage mempengaruhi audit delay secara positif. Hal ini terjadi karena tingkat leverage mencerminkan kinerja buruk perusahaan. Kinerja buruk ini mungkin saja terjadi akibat manajemen yang buruk. Hal ini akan membuat auditor melakukan audit lebih dalam sehingga membutuhkan waktu yang lebih lama.

Variabel lain bernilai tidak signifikan Pengumuman rugi. Pengumuman rugi memiliki nilai signifikansinya sebesar 0,11 artinya variabel ini nilai signifikansinya lebih dari 0,10. Variabel ini juga memiliki koefisien yang bernilai positif. Dari data tersebut maka dapat diambil kesimpulan H4 dalam penelitian ditolak. Hal ini berarti tidak terdapat pengaruhnya antara pengumuman rugi perusahaan terhadap ketepatan waktu penerbitan laporan keuangan perusahaan. Hasil penelitian ini sejalan dengan penelitian

Haron et al. (2006) yang berhasil menemu-kan bahwa laba/rugi operasi secara signifikan tidak berpengaruh terhadap audit delay. Hal ini berkaitan dengan ketidakstabilan kondisi ekonomi saat ini, dimana kebanyakan perusahaan yang mengalami kerugian diabaikan dalam pelaporan keuangannya karena kerugian dianggap sebagai hal yang biasa. Namun, Hal ini bertolak belakang dengan penelitian yang dilakukan oleh Yaacob dan Ayoib (2012), Wiwiek Utami (2006), Ahmed (2003). Dalam penelitiannya Yaacob dan Ayoib (2012) 
menemukan bahwa terdapat hubungan yang signifikan antara pengumuman rugi dan ketepatan waktu penyajian laporan keuangan. Hal ini karena biasanya perusahaan yang mengalami kerugian akan meminta auditor menunda penerbitan laporan auditan sehingga "bad news" tidak begitu mempengaruhi keputusan yang akan diambil stakeholder.

Variabel kualitas auditor merupakan variabel lain yang bernilai signifikan karena nilai signifikansinya dibawah 0,10 dengan koefisien yang bernilai negatif. Variabel ini memiliki nilai signifikansi sebesar 0,05. Dengan begitu pada kesimpulan ini besarnya Kantor Akuntan Publik memiliki pengaruh negatif terhadap ketepatan waktu penyajian laporan keuangan, maka H5 dalam penelitian diterima. Hasil yang sama didapat oleh penelitian yang dilakukan Iskandar dan Trisnawati (2010). Mereka menemukan bahwa Perusahaan yang diaudit oleh KAP berafiliasi dengan big four mengalami audit report lag yang lebih pendek. Hal ini karena menurut Ahmad dan Kamarudin (2003) dalam Iskandar dan Trisnawati (2010), KAP yang lebih besar dinilai lebih mampu melaksanakan audit secara efisien dan lebih efektif daripada KAP yang lebih kecil serta memiliki fleksibilitas dalam menjadwal pelaksanaan audit sehingga audit dapat diselesaikan secara tepat waktu. Selain itu, KAP besar diyakini dapat memberikan keyakinan yang lebih mengenai kualitas auditor.

\section{SIMPULAN}

Hasil analisis menunjukkan ukuran perusahaan, leverage, dan kualitas auditor mempengaruhi secara signifikan audit delay pada tingkat yang berbeda. Variabel ukuran perusahaan dan kualitas auditor berpengaruh secara negatif terhadap audit delay, sedangkan tingkat leverage mempengaruhi secara positif audit delay. Dua variabel lain sisanya bernilai tidak signifikan. Variabel tersebut adalah penerapan IFRS dan pengumuman rugi.

Manfaat penelitian antara lain menjadi bahan evaluasi terutama bagi Kantor Akuntan Publik (KAP) dalam menyiapkan para auditornya dalam menghadapi perubahan Standar Akuntansi Keuangan (SAK). Selain itu, hasil penelitian ini juga dapat menjadi bahan evaluasi bagi Dewan Standar Akuntansi Keuangan (DSAK) dalam mengkaji dampak PSAK baru yang berbasis IFRS terhadap lamanya proses audit. Hasil penelitian ini juga berkontribusi bagi literatur akuntansi dengan memberikan bukti empiris dampak konvergensi IFRS di negara code law seperti Indonesia.

Penelitian ini memiliki beberapa keter-batasan diantaranya definisi audit delay pada penelitian ini belum memperhitungkan waktu perikatan karena definisi audit delay yang digunakan pada penelitian ini mengacu pada penelitian sebelumnya. Selain itu, Populasi dari penelitian hanya terbatas pada perusahaan manufaktur saja sehingga hasil hanya terbatas pada perusahaan manufaktur. Pada penelitian ini juga dapat dilihat dari kemampuan variabel independen dalam menjelaskan varians variabel audit delay pada model penelitian sebesar 5\%, berarti sejumlah 95\% persen varians dapat dijelaskan oleh faktor lain diluar model dan variabel independen yang digunakan hanya terbatas pada lima variabel.

Keterbatasan lain adalah pengunaan proksi dalam pengukuran implementasi IFRS dengan variabel dummy. Atas dasar keterbatasan tersebut, untuk penelitian selanjutnya disarankan agar Definisi audit delay yang digunakan sebaiknya memperhatikan waktu perikatan audit, agar definisi tersebut lebih tepat digunakan. Selanjutnya, sebaiknya industri yang digunakan tidak terbatas pada industri manufaktur. Penelitian mendatang dapat mengembangkan pengukuran variabel implementasi IFRS selain dengan variabel dummy misalnya dengan menganalisis implementasi PSAK 
berbasis IFRS. Saran terakhir, sebaiknya variabel independen yang digunakan lebih banyak lagi dan mencari variabel baru untuk diteliti.

\section{DAFTAR PUSTAKA}

Ahmed, K. 2003. The timeliness of corporate reporting: a comparative study of South Asia. Advance in International Accounting, 16, 1743.

Febrianty. 2011. Faktor-Faktor Yang Berpengaruh Terhadap Audit delay Perusahaan Sektor Perdagangan Yang Terdaftar di BEI Periode 2007-2009. Jurnal Ekonomi dan Informasi Akuntansi (Jenius), 1 (3), 294-320

Ghozali, Imam. 2011. Aplikasi Analisis Multivariate dengan Program SPSS. Semarang: Badan Penerbit Universitas Diponegoro.

Haron, H, B. Hartadi, dan E. Subroto. 2006. Analysis of factors influencing audit delay (Empirical Study at Public Companies in Indonesia), Jurnal Riset Akuntansi Indonesia, 6 (1), 95-121

Haryani, J. dan Wiratmaja. 2014. Pengaruh ukuran perusahaan, komite audit, penerapan IFRS dan kepemilikan publik pada Audit Delay, EJurnal Akuntansi Universitas Udayana 6 (1), 63-78

Iskandar, M. J. dan Tisnawati. 2010. Faktor-Faktor yang mempengaruhi audit Report Lag pada perusahaan yang terdaftar di Bursa Efek Indonesia, Jurnal Bisnis dan Akuntansi 12 (3),175-186.

Kartika, A. 2009. Faktor-Faktor Yang Mempengaruhi Audit Delay di Indonesia. Jurnal Bisnis dan Ekonomi, 16 (1), 1-17.

Margaretta, S. 2011. Pengaruh penerapan IFRS terhadap keterlambatan waktu penyampaian laporan keuangan pada perusahaan manufaktur yang terdaftar di Bursa Efek Indonesia. Skripsi, Universitas Bina Nusantara.

Owusu-Ansah, S. 2000. Timeliness of corporate financial reporting in emerging capital market: Empirical evidence from The Zimbabwe Stock Exchange. Journal Accounting and Business Research, 30 (3), 241-254

Utami, W. 2006. Analisis determinan audit delay: Kajian empiris di Bursa Efek Jakarta. Bulletin penelitian, (09), 1-14.

Yaacob, N. M. dan C. A. Ayoib. 2011. IFRS adoption and audit timeliness: Evidence from Malaysia. The Journal of American Academy of Business, 17, 122-118.

Yaacob, N. M. dan C. A. Ayoib. 2012. Adoption of FRS 138 and audit delay in Malaysia". International Journal Of Economic and Finance, 4 (1), 167-179. 